University of South Florida

DIGITAL COMMONS

Digital Commons @ University of @ UNIVERSITY OF SOUTH FLORIDA

South Florida

\title{
Implications of Subduction Rehydration for Earth's Deep Water Cycle
}

\author{
Lars Rüpke \\ University of Oslo \\ Jason Phipps Morgan \\ Cornell University \\ Jacqueline Eaby Dixon \\ University of Miami, jdixon@usf.edu
}

Follow this and additional works at: https://digitalcommons.usf.edu/msc_facpub

Part of the Life Sciences Commons

\section{Scholar Commons Citation}

Rüpke, Lars; Phipps Morgan, Jason; and Dixon, Jacqueline Eaby, "Implications of Subduction Rehydration for Earth's Deep Water Cycle" (2006). Marine Science Faculty Publications. 1314.

https://digitalcommons.usf.edu/msc_facpub/1314

This Book Chapter is brought to you for free and open access by the College of Marine Science at Digital Commons @ University of South Florida. It has been accepted for inclusion in Marine Science Faculty Publications by an authorized administrator of Digital Commons @ University of South Florida. For more information, please contact digitalcommons@usf.edu. 


\title{
Implications of Subduction Rehydration for Earth's Deep Water Cycle
}

\author{
Lars Rüpke \\ Physics of Geological Processes, University of Oslo, Oslo, Norway, and \\ SFB 574 Volatiles and Fluids in Subduction Zones, Kiel, Germany \\ Jason Phipps Morgan \\ Cornell University, Ithaca, New York, USA and SFB 574 Volatiles and \\ Fluids in Subduction Zones, Kiel, Germany \\ Jacqueline Eaby Dixon \\ RSMAS/MGG, University of Miami, Miami, Florida, USA
}

The "standard model" for the genesis of the oceans is that they are exhalations from Earth's deep interior continually rinsed through surface rocks by the global hydrologic cycle. No general consensus exists, however, on the water distribution within the deeper mantle of the Earth. Recently Dixon et al. [2002] estimated water concentrations for some of the major mantle components and concluded that the most primitive (FOZO) are significantly wetter than the recycling associated EM or HIMU mantle components and the even drier depleted mantle source that melts to form MORB. These findings are in striking agreement with the results of numerical modeling of the global water cycle that are presented here. We find that the Dixon et al. [2002] results are consistent with a global water cycle model in which the oceans have formed by efficient outgassing of the mantle. Present-day depleted mantle will contain a small volume fraction of more primitive wet mantle in addition to drier recycling related enriched components. This scenario is consistent with the observation that hotspots with a FOZO-component in their source will make wetter basalts than hotspots whose mantle sources contain a larger fraction of EM and HIMU components.

\section{INTRODUCTION}

The presence of running water is one of the key distinctions between the Earth and other planets in the solar system. The obvious surface expression of this is the global

Earth's Deep Water Cycle

Geophysical Monograph Series 168

Copyright 2006 by the American Geophysical Union. $10.1029 / 168 \mathrm{GM} 20$ ocean that covers some $71 \%$ of Earth's surface. Although the origin of the oceans is still under debate, current conventional wisdom is that they are exhalations from the Earth's interior (see [Drake and Righter, 2002] for a review). The 'hidden oceans' that may exist inside the Earth's deep interior remain, however, elusive and with them the question of water distribution inside the deeper Earth. Mineral physics tells us that upper mantle rocks, especially transition zone rocks, have the chemical ability to incorporate significant 
amounts of water into their crystal structure [Hirschmann, et al., 2005; Ohtani, 2005; Smyth, 1987; Williams and Hemley, 2001] — up to several oceans worth of water. Geochemical evidence seems to show a different and drier picture of the Earth's mantle. Dixon et al. [2002] have recently determined water concentrations in various OIB and MORB type basaltic rocks and found a maximum water concentration of only $\sim 750$-ppm for the most primitive source components (FOZO) - see Table 1 for an explanation of the used terminology. FOZO appears therefore to be wettest mantle component - wetter than average mantle and the even drier depleted MORB source.

Here we will briefly review the geochemical evidences before presenting the results of a numerical model for the chemical evolution of the Earth. This model puts some constraints on how mantle outgassing and potential regassing through plate subduction may have evolved through time.

\subsection{Mantle Geochemistry}

The sources of both mid-ocean ridge basalts (MORB) and ocean island basalts (OIB) contain several isotopically distinct source components (e.g. [Zindler and Hart, 1986]; see [Hofmann, 1997] for a review) which leave their fingerprints on observed basalts to which their melts contribute, with arrays of basalts produced at a given hotspot typically occupying a tubelike subregion in the isotope-space spanned by terrestrial basaltic volcanism [Hart, et al., 1992; Phipps Morgan, 1999]. It is now generally agreed that at least several of the isotopically most extreme components contain material that was originally formed by melting and alteration processes near Earth's surface and then recycled by plate subduction back into the mantle to rise and melt beneath present-day hotspots and mid-ocean ridges [Chase, 1979; Hofmann, 1997; Hofmann and White, 1982]. Two
'Enriched mantle' source components EM1 and EM2 and the HIMU source component are believed to have formed in this way through the recycling of sediments and OIB for the EM components, and the recycling of the lower MORB crust for the HIMU component. Another mantle component called 'FOZO' appears to be linked to the melting of the most primitive, undifferentiated, and undegassed component of the mantle mélange. In particular, the partial melting of this component correlates with highest ${ }^{3} \mathrm{He} /{ }^{4} \mathrm{He}$ ratios in basalts erupted at ocean islands and mid-ocean ridges. Other, more incompatible trace element-poor and isotopically depleted components have also been inferred, in particular the prevalent depleted DMM component evident in many MORB.

Recently Dixon and coworkers have measured the water contents of the DMM, FOZO, EM1 mantle components and inferred the value for HIMU [Dixon, et al., 2002]. During mantle melting beneath hotspots and ridges, water partitions from a source component into its melt with roughly the same affinity for the melt phase as the light rare-earth element $\mathrm{Ce}$, i.e. it behaves as a moderately incompatible element during pressure-release melting. Even though both the EM and HIMU mantle components are much richer in incompatible elements than the mantle average, Dixon et al. [2002] found that the recycled EM and HIMU components have lower ratios of water to cerium $\left(\mathrm{H}_{2} \mathrm{O} / \mathrm{Ce} \sim 100\right)$ than either typical MORB source $\left(\mathrm{H}_{2} \mathrm{O} / \mathrm{Ce} \sim 150-250\right)$ [Michael, 1995] or FOZO-influenced OIB (e.g. $\mathrm{H}_{2} \mathrm{O} / \mathrm{Ce} \sim 210$ Pacific-South Atlantic, 250 North Atlantic, 190 Kilauea source, and up to 350 for the metasomatized source for the peripheral Hawaii alkalic basalts [Dixon and Clague, 2001]). This implies in terms of absolute water abundances that the FOZO source has an average of 750 \pm 210 -ppm water [Dixon, et al., 2002; Simons, et al., 2002]. This value is consistent with the estimate by [Asimow, et al., 2004] who give a value of 700-ppm for the Azores plume end-member and [Nichols, et al., 2002] who calculated that

Table 1. Glossary of the used terminology.

\begin{tabular}{|c|c|}
\hline mantle outgassing & $\begin{array}{l}\text { water loss from the mantle to the atmosphere during mantle melting at mid-ocean ridges } \\
\text { and hotspots. }\end{array}$ \\
\hline $\begin{array}{l}\text { mantle regassing / } \\
\text { water recycling }\end{array}$ & water transport from the surface back into the mantle by plate subduction. \\
\hline exosphere & oceans (hydrosphere) and continental crust \\
\hline ppm & parts per million - by weight - is equivalent to $\mathrm{mg} / \mathrm{kg}$ \\
\hline MORB & mid-ocean ridge basalt is made by melting of asthenospheric mantle at mid-ocean ridges \\
\hline OIB & ocean island basalt is produced by melting of plume mantle at hotspots. \\
\hline FOZO & $\begin{array}{l}\text { focal zone - a common geochemical mixing end-member that probably represents the most } \\
\text { primitive mantle component; sometimes also called 'C' (or 'PHEM') }\end{array}$ \\
\hline HIMU & $\begin{array}{l}\text { mantle end-member that is characterized by a high } \mu={ }^{238} \mathrm{U} / 204 \mathrm{~Pb} \text { ratio and that is } \\
\text { associated with the recycling of subducting plates. }\end{array}$ \\
\hline EM-1 / EM-2 & $\begin{array}{l}\text { enriched mantle - mantle end-members that are thought to result from the subduction of } \\
\text { sediments (and sometimes from the recycling of OIB). }\end{array}$ \\
\hline DMM & depleted MORB mantle \\
\hline
\end{tabular}


the enriched mantle end-member under Iceland has $770 \pm 150$ ppm $\mathrm{H}_{2} \mathrm{O}$. All these estimates depend strongly on the assumed degrees of melting but regardless of assumptions it is safe to say that all recent estimates for water concentrations in the FOZO component are below 1000-ppm and that the estimate used here from [Simons, et al., 2002] of 750-ppm is representative. The average source for mid-ocean ridge basalts has less water and contains about $\sim 100$-ppm while the source of the more depleted MORB has a water abundance of $\sim 60-\mathrm{ppm}$. Dixon et al. [2002] concluded that the high $\mathrm{H}_{2} \mathrm{O} / \mathrm{Ce}$ in the FOZO source component cannot be derived from recycled oceanic crust, and that instead a significant amount of the water in the FOZO component must be juvenile, left over from planetary accretion. They also concluded that the EM and HIMU components lost most of their chemicallybound water, but not their incompatible rare-earth elements by subduction-induced slab-dehydration. These absolute water concentrations in mantle rocks and conclusions on preferential slab-dehydration of recycled sediments and ocean crust put some constraints on possible mantle evolution scenarios. Here we present results of numerical modeling of the Earth's global water cycle and explore which evolution scenarios for the mantle's hydration state are consistent with the geochemical data.

\section{EARTH'S DEEP WATER CYCLE}

We model the Earth's deep water cycle by assuming that the mantle's present hydration state represents the long-term product of the competing processes water outgassing at midocean ridges and hotspots and mantle regassing at subduction zones. This scenario is illustrated in Fig. 1: oceanic plates become hydrated during their stay at the ocean floor. Upon subduction, most of this water is released and brought back to the surface by arc magmatism and fore-arc fluid venting. Some chemically bound water subducts past the region of sub-arc desiccation to rehydrate the deeper mantle. This deeply subducted water mixes efficiently with the convecting mantle. During mantle upwelling and melting at mid-ocean ridges and hotspots, water is outgassed from the mantle into the hydrosphere thereby 'closing' the global geologic water cycle.

This type of mantle evolution scenario depends on four principle input parameters: (1) the amount of subducted water, (2) the efficiency of water outgassing during mantle melting, (3) mantle overturn rates, and (4) the present-day amount of 'non-mantle' exosphere water, i.e. water in the oceans and in the continental crust.

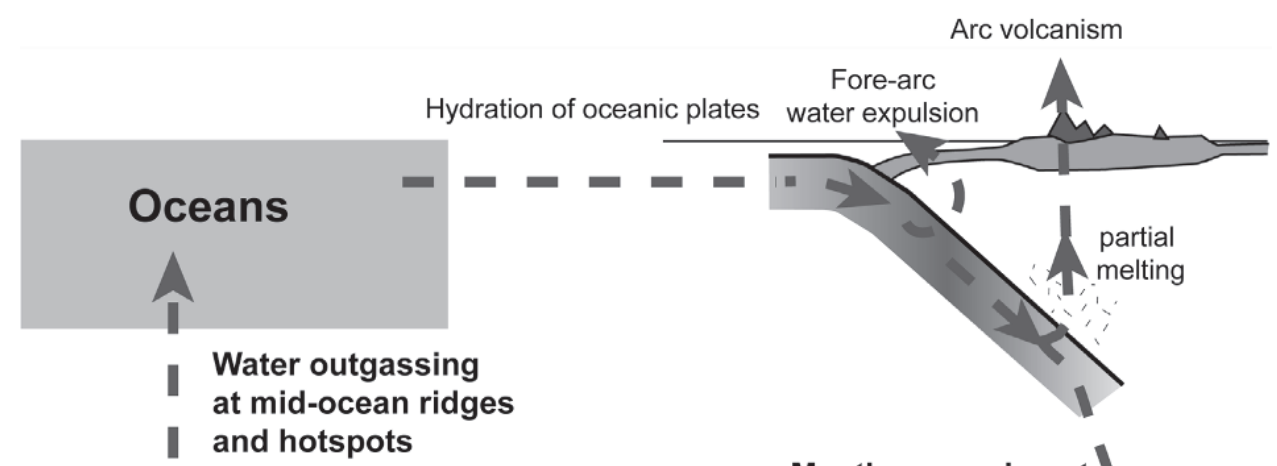

Mantle regassing at 1
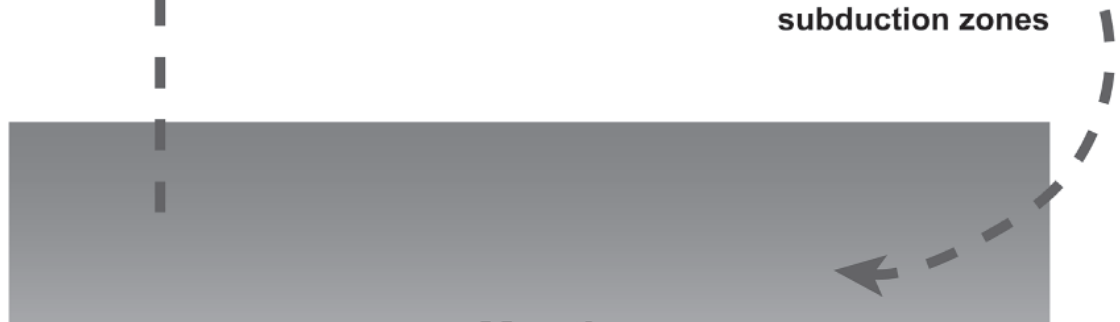

Mantle

Figure 1. Earth's geologic water cycle. The mantle's hydration state is controlled by the competing processes water outgassing at ridges and hotspots and water regassing through plate subduction. 


\subsection{Hydration and Dehydration of Oceanic Plates}

Oceanic plates undergo a variety of alteration processes during their lifetime on the ocean floor. Hydration starts during ocean crust formation at mid-ocean ridges. Fractures within the young ocean crust lead to seawater infiltration and hydrothermal alteration. After this initial hydration phase the oceanic crust experiences continuous low temperature alteration during its lifetime at the ocean floor. Staudigel, et al., [1996] give an estimate of about $2.7 \mathrm{wt} . \%$ water within the highly altered upper part of mature oceanic crust. The deeper parts of the crust contain less water and estimates range from almost zero to $1.0 \mathrm{wt} \%$. In addition to crustal hydration, sediments containing both chemically bound and pore water are deposited onto oceanic lithospheric plates. Plank and Langmuir, [1998] formulated an average sediment composition that they call GLOSS. GLOSS contains about $7 \mathrm{wt} \%$ of chemically bound water. If we assume an average sediment thickness of $500 \mathrm{~m}$ and that the $8 \mathrm{~km}$ thick crust is made of one kilometer of highly altered basalt $(2.7 \mathrm{wt} \%$ $\left.\mathrm{H}_{2} \mathrm{O}\right)$, two kilometers of less hydrated $\left(1 \mathrm{wt} \% \mathrm{H}_{2} \mathrm{O}\right)$ and $5 \mathrm{~km}$ of almost dry rocks we obtain a total water content of about $2.5 \times 10^{5} \mathrm{~kg}$ below each square meter of ocean floor (Plate 1). Note that this number gives the total amount of water in crustal and sedimentary rocks in a column of ocean floor and is a conservative estimate; Schmidt and Poli, [1998] give an estimate of up to $6.0 \times 10^{5} \mathrm{~kg} / \mathrm{m}^{2}$ but assume almost water saturated conditions and Peacock's [1990] estimate for water subduction rates translates into $3.35 \times 10^{5} \mathrm{~kg} / \mathrm{m}^{2}$.

These two hydration processes, sediment deposition and crustal alteration, are now well established. However, recent geophysical observations indicate that in addition the cold lithospheric mantle may become hydrated during plate bending. Ranero, et al., [2003] showed that normal faulting during plate bending may provide the pathways for seawater to reach and react with cold lithospheric mantle to make serpentine, i.e. to hydrate it. Heat flow studies [Grevemeyer, et al., 2005] and refraction seismic experiments offshore Nicaragua seem to confirm this finding by showing reduced sub-Moho p-wave velocities consistent with 10-20\% serpentinization [Grevemeyer, et al., 2006]. Furthermore, oceanic lithospheric mantle may also become serpentinized during seawater infiltration during plate formation at mid-ocean ridges. In fact, Marone et al., [2003] may have imaged a serpentinized sub-Moho mantle in the NE Atlantic Ocean. If we assume that slabs contain a $5 \mathrm{~km}$ thick layer that is $10 \%$ serpentinized [Schmidt and Poli, 1998] we end up with another $2.1 \times 10^{5} \mathrm{~kg} / \mathrm{m}^{2} \mathrm{H}_{2} \mathrm{O}$ in a column of lithospheric mantle. The total water content of slabs is therefore on the order of $4.6 \times 10^{5} \mathrm{~kg} / \mathrm{m}^{2}$ chemically bound within (1) sediments, (2) crust, and (3) serpentinized mantle. This value can be seen as an average value for present-day water contents of subducting oceanic plates.

Key to understanding the role of plate subduction in the global geologic water cycle is the amount of water that may survive sub-arc water release to be recycled back into the deeper mantle. We have recently explored deep water recycling by plate subduction using a chemo-thermo-dynamical model [Rüpke, et al., 2002; Rüpke, et al., 2004]. We found that at the coldest present-day subduction zones up to one third of the subducted water may be transported into the deeper mantle. Young and hot subduction zones are characterized by very efficient plate dehydration so that almost no water is transported into the deeper mantle. An upper bound for the amount of water that is presently subducted into the deeper mantle is therefore about $1.6 \times 10^{5} \mathrm{~kg} / \mathrm{m}^{2}$.

In order to understand which role subduction rehydration played for the chemical evolution of the mantle we have to constrain water recycling throughout Earth's history. As no consensus exists on when plate tectonics emerged and what past-subduction might have looked like, we have to explore a wide parameter range to constrain water recycling over geologic time scales. We assume that plate subduction has been sufficiently cold since $2 \mathrm{Ga}$ to recycle water into the deeper mantle and that the amount of water retained in slabs increased linearly from zero at the onset of 'cold' subduction to a given present-day value. This present-day value is assumed to vary by factors between 0 and 2 around the average value of $1.6 \times 10^{5} \mathrm{~kg} / \mathrm{m}^{2}$ given above. As these estimates give total water retention per square meter of subducted ocean floor, the spreading (or subduction) rates must also be known though time in order to determine absolute recycling rates.

\subsection{Convection, Mixing and Outgassing}

To constrain the mantle flow pattern throughout Earth's history we assume whole mantle flow and follow Phipps Morgan's, [1998] approach of inferring mantle overturn rates from the changing radiogenic heat production during Earth's history. From this it follows that mantle overturn rates have exponentially decreased by a factor of about 25 during Earth's history (Fig. 2).

Furthermore, we assume that any water recycled back into the mantle at subduction zones is instantaneously mixed into the convecting mantle. The 'true' characteristic mixing time of the mantle is certainly higher - maybe even on the order of Ga [Ten, et al., 1998]. We, however, neglect the complexity of mantle mixing and assume instantaneous mixing. Furthermore, we neglect possible preferential water storage in the mantle (i.e. the transition zone) - an assumption that is supported by numerical modeling. Richard, et al., [2002] 


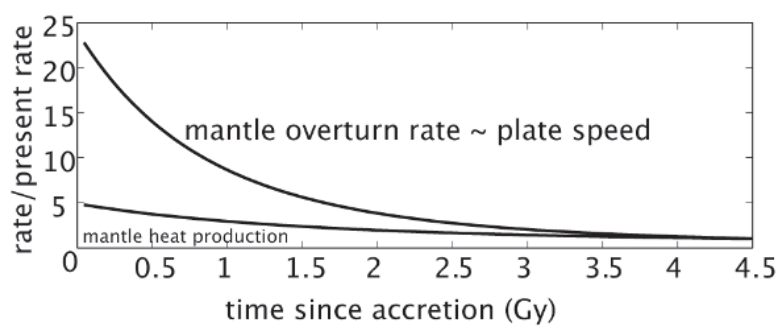

Figure 2. Mantle overturn rates through time. We assume a parameterized mantle convection scenario in which radiogenic heat production is balanced by convective cooling. This assumption yields that mantle overturn rates have decreased by a factor of about 25 through time (see [Phipps Morgan, 1998] for details).

showed that mantle water follows the convective flow pattern and that preferential water storage inside the mantle is unlikely.

Mantle water is outgassed during mantle melting at hotspots and mid-ocean ridges. The efficiency of water outgassing is controlled by the 'incompatibility' of water during mantle melting and the solubility of water in the produced melts. While it is clear that water partitions readily into the melt phase (see e.g. [Asimow, et al., 2004] for D-values), the solubility of water is somewhat less well constraint. Water solubility in near-surface melts is very low so that it is efficiently outgassed during sub-aerial hotspot volcanism. At mid-ocean ridges, at $2500 \mathrm{~m}$ water depth, water solubility in melts is higher. However, the MORB source is dry and depleted and may have experienced a primary melting event during plume melting [Phipps Morgan and Morgan, 1999]. It thus appears that $50 \%$ is a lower bound for water outgassing efficiency during mantle melting, i.e. half of the primary mantle water during melting at hostspots, mid-ocean ridges, and arcs is outgassed into the atmospheres. Our preferred values would be higher $(>90 \%)$. However, since we do not have tight constraints on mantle outgassing efficiencies we systematically vary it between $30 \%$ and $99 \%$ in the model runs. Absolute water outgassing rates thus depend on the outgassing efficiency, the melting mantle's water content and on the assumed spreading or mantle overturn rates.

\subsection{Water on the Earth's Surface}

The global ocean is the primary liquid water reservoir on Earth's surface. Together with ground water, glaciers, atmospheric water, etc. we end up with a total of $1.46 \times 10^{21} \mathrm{~kg}$ of surface water. While the amount of water in the oceans is relatively well constrained the amount of water chemically bound in the continental crust is not. Estimates of the present-day volume of continental crust give a value of about $7.8 \times 10^{9} \mathrm{~km}^{3}$ [Mooney, et al., 1998; Nataf and Ricard, 1996].
Assuming an average density of $2700 \mathrm{~kg} / \mathrm{m}^{3}$ [Stacey, 1992] and an average water concentration of 1-3 wt.\% [Henderson, 1986], we end up with another $(2.1-6.3) \times 10^{20} \mathrm{~kg}$ of water in the continental crust. The total amount of 'non-mantle' exosphere water is therefore between $1.67 \times 10^{21} \mathrm{~kg}$ and $2.09 \times 10^{21} \mathrm{~kg}$. As these numbers are again only estimates we systematically vary the Earth's present-day exosphere water content in the models in order to quantify which effects it has on the modeling results.

Now we have assembled all the ingredients needed to formulate the governing equations of the model:

$$
\begin{aligned}
& \frac{\partial \mathrm{H}_{2} \mathrm{O}_{\text {man }}}{\partial t}=-f_{\mathrm{H}_{2} \mathrm{O}} * R(t) * \mathrm{H}_{2} \mathrm{O}_{\text {man }}(t)+S(t) \\
& \frac{\partial \mathrm{H}_{2} \mathrm{O}_{\text {exo }}}{\partial t}=f_{\mathrm{H}_{2} \mathrm{O}} * R(t) * \mathrm{H}_{2} \mathrm{O}_{\text {man }}(t)-S(t) \\
& R(t)=\frac{Q^{2}}{R_{0}} \\
& S(t)=s(t) * s_{0} * Q^{2} \\
& \mathrm{H}_{2} \mathrm{O}_{\text {man }}(0)=\mathrm{H}_{2} \mathrm{O}_{\text {initial }} \\
& \mathrm{H}_{2} \mathrm{O}_{\text {exo }}(\text { end })=\mathrm{H}_{2} \mathrm{O}_{\text {ocean }}
\end{aligned}
$$

Here $R(t)=Q^{2}(t) / R_{0}$ is the 'paleo-mantle-processing-rate' of the mantle, $R_{0}=9.8 G a$ is the present-day mantle overturn rate, $Q(t)$ is radiogenic heating through time normalized to the present-day value, and $f_{H 2 O}$ is the water outgassing efficiency during mantle melting. $S(t)$ is the water recycling (mantle regassing) rate through plate subduction, $s(t)$ the recycling pre-factor, and $s_{0}=1.6 \times 10^{5} \mathrm{~kg} / \mathrm{m}^{2} \times 2.7 \times 10^{15} \mathrm{~m}^{2} / \mathrm{Ga}$ $=4.16 \times 10^{20} \mathrm{~kg} / \mathrm{Ga}$ is the present-day water subduction rate with the second number being the present-day spreading rate. Please refer to [Phipps Morgan, 1998] for a discussion of the values chosen for the present-day spreading and mantle overturn rate. $\mathrm{H}_{2} \mathrm{O}_{\text {ocean }}$ is the present-day water content of the exosphere as discussed above. Solving these equations yields a first order approximation of the Earth's deep water cycle.

\section{A MANTLE EVOLUTION SCENARIO}

\subsection{The Mutual Effect of Model Parameters}

Figure 3 shows six example calculations for the geologic water cycle through time. Every model is tuned to reproduce the present day conditions, i.e. the model reproduces the surficial water mass currently found in Earth's continental crust and oceans. As model parameters we assume that water recycling starts $2 \mathrm{Ga}$ ago and that the continental crust contains 2 wt. $\%$ of water. To exemplify the effect of subduction rehydration in (a) a recycling pre-factor of 0.5 is assumed 

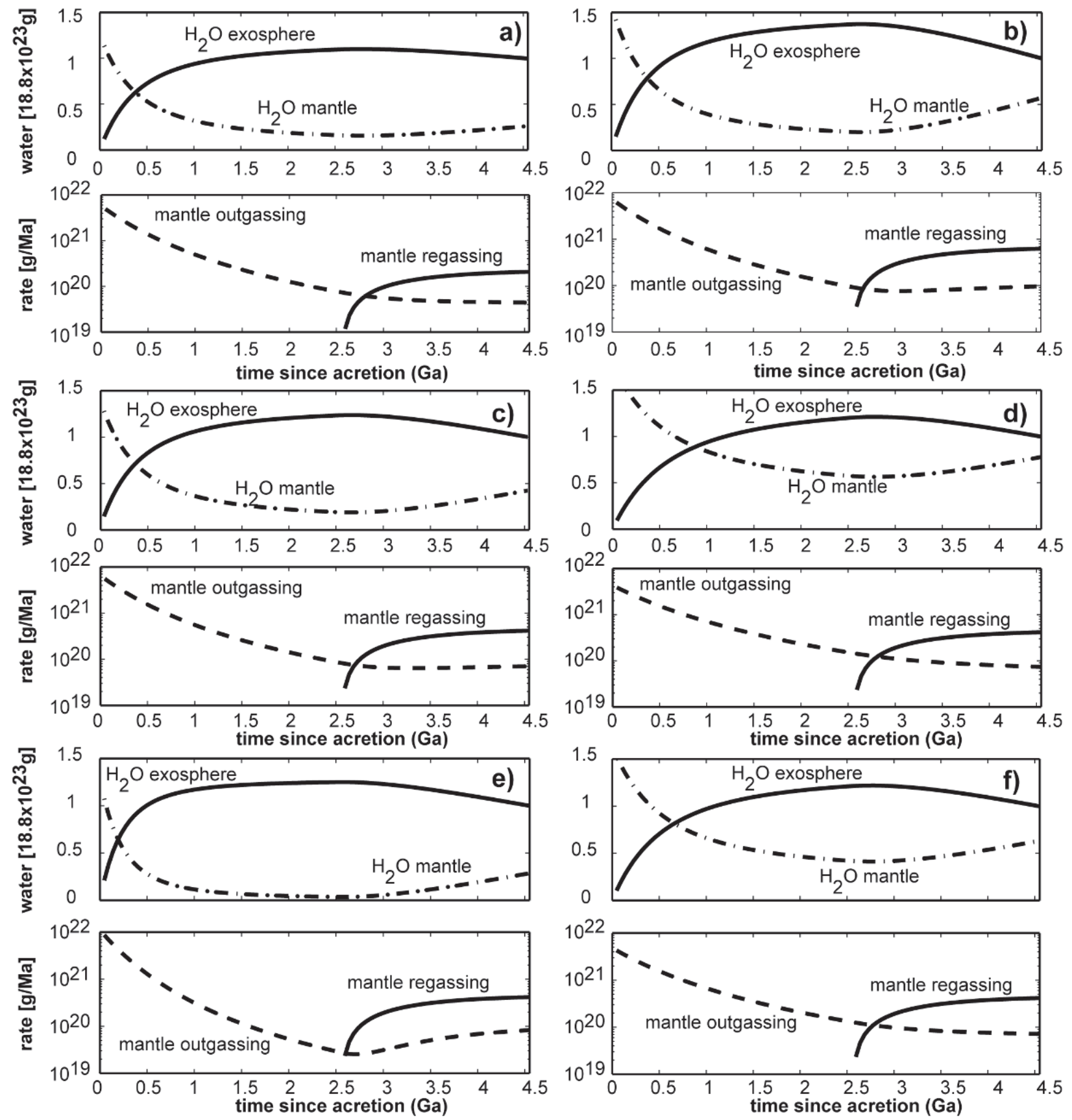

Figure 3. Modeled Earth's geologic water cycle. The plots (a-f) show different evolution scenarios for the Earth's mantle and oceans assuming different water recycling functions and water outgassing efficiencies through time (see Table 2 and text for details). In (a-b) the present-day mantle overturn rate is $9.8 \mathrm{Ga}$ while in (e) it is $5.7 \mathrm{Ga}$ and in (f) $14.7 \mathrm{Ga}$.

so that $2.08 \times 10^{20} \mathrm{~g} \mathrm{Ma}^{-1}$ of water are presently recycled into the mantle in (b) this pre-factor is 1.5 and $6.24 \times 10^{20} \mathrm{~g} \mathrm{Ma}^{-1}$ of water are recycled; outgassing efficiency is $90 \%$ in both models. The starting conditions that reproduce the presentday conditions are 1.26 in (a) and 1.57 exospheres in (b) of water initially dissolved in the mantle. In both models high mantle water contents and high overturn rates in the beginning of Earth history lead to efficient water ougassing and formation of the oceans while the mantle progressively desiccates. Peak sea-level conditions are reached about $2 \mathrm{Ga}$ ago when mantle regassing through cold plate subduction starts to dominate over water ougassing through mantle melting. 

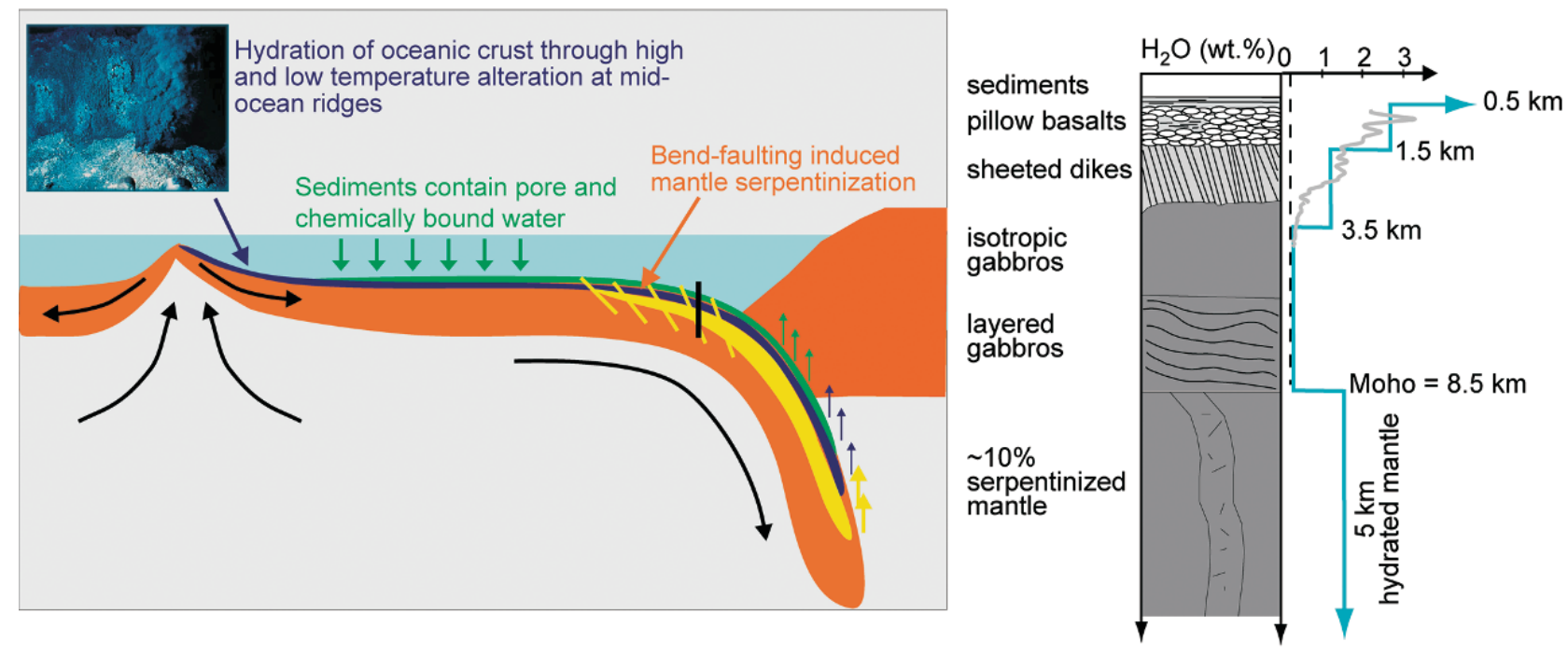

Plate 1. Hydration of oceanic plates. Ocean crust becomes hydrated through hydrothermal alteration at mid-ocean ridges and through low-temperature alteration at the sea floor. Sediments contain both chemically bound and pore water. Bendfaulting at the trench outer rise may lead to additional hydration of the cold lithospheric mantle. 
As a consequence the mantle slowly rehydrates. Depending on the assumed water recycling rate the present-day conditions are characterized by a mantle that has lost $79 \%$ and $64 \%$, respectively, of its initial water and presently contains $26 \%$ and $57 \%$, respectively, of the water in the exosphere. In the absence of subduction rehydration, the mantle would have lost $90 \%$ of its initial water. This shows that in both cases the present-day mantle has lost a significant part of its initial water to form the oceans and that plate subduction plays an important role in rehydrating the mantle.

In (c) and (d) we assume the same present-day water regassing rates of $4.16 \times 10^{20} \mathrm{~g} \mathrm{Ma}^{-1}$ and vary water outgassing efficiency between $90 \%$ (c) and $50 \%$ (d). As expected reducing the mantle ougassing efficiency increases the amount of initial water in the mantle that is necessary to reproduce the present-day conditions (1.41 in (c) and 1.78 in (d)). The present-day conditions are characterized by a mantle that has lost $71 \%$ in (c) and $56 \%$ in (d) of its initial water and presently contains $42 \%$ to $78 \%$ of the water presently stored in the exosphere. In the absence of subduction the mantle would have lost $90 \%$ and $72 \%$ of its water, respectively.

In (e) and (f) we have varied the present-day mantle processing rate. In all other model runs we assume a mantle processing rate of $9.8 \mathrm{Ga}$, which is a relatively robust estimate that is based on the present-day spreading rate-see [Phipps Morgan, 1998] for details. However, to illustrate the effect of changing mantle processing rates we assume a faster rate of $5.7 \mathrm{Ga}$ in (e) and $14.7 \mathrm{Ga}$ in (f). Note, that the faster rate has been suggested by [Kellogg and Wasserburg, 1990]. Faster, processing rates result in very rapid and efficient mantle outgassing early during Earth's history. Slower rates prolong the time to form the oceans. In order to put these values into perspective we have summarized the results in Table 2 and compared them to previous studies.

These six example model runs give some initial insights into how subduction rehydration and water outgassing affect the evolution of the Earth: raising water recycling by plate subduction has a similar effect as lowering water outgassing efficiency — both lead to higher present-day and initial water contents of the Earth's mantle. A somewhat surprising effect of lowering the outgassing efficiency is that this does not lead to lower absolute water outgassing rates (see Table 2, run $\mathrm{c}$ and d). In fact, less effective water outgassing leads to a wetter mantle, which increases again the water outgassing rates. This implies that the outgassing efficiency is directly related to the present-day water content of the mantle-the lower the outgassing efficiency the more water is in the mantle. Another effect of lowering the water outgassing efficiency is that the time to form the oceans is prolonged.

In order to give a more complete picture of how the different model parameters affect the results we have performed some 1500 model runs and plotted the results in phase diagrams in Plate 2. Inspecting these results shows that for a wide parameter range the mantle will have lost most of its water to the exosphere and contains presently much less water than the exosphere. Only for very high rehydration pre-factors, i.e. mantle regassing rates, and very low water outgassing efficiencies can the mantle reach equal or higher water contents as the exosphere. This shows that the model for the global geologic water cycle that is presented here favors a 'dry' mantle over a 'wet' mantle. Note, that these numbers imply whole mantle flow, so that eventually most of the mantle participates in near-surface upwelling, melting, and differentiation processes. If a strictly layered Earth is assumed to have always existed, it is possible that a reservoir of incommunicative 'primitive' mantle water exists that would still not yet have 'participated' in the surface + communicative mantle geologic water cycle and water distribution between the oceans and the mantle.

\subsection{Comparison to Geochemical Constraints}

The above results show that for every combination of model parameters there is one starting condition that re-produces the present-day oceans. This implies that more constraints are needed to make somewhat less ambiguous predictions on how the global water cycle has evolved through time and what the present hydration state of the mantle is. As additional constraints we use the water concentrations in different mantle end-members that were determined by Dixon et al., [2002]. To compare our findings to geochemical data we translate our findings on water distribution between the exosphere and the mantle into average water concentrations in different mantle components (Plate 3). To make predictions for the most primitive mantle components (FOZO) we assume that all the initial water in the mantle is dissolved in the $4.0 \times 10^{24} \mathrm{~kg}$ [Stacey, 1992] of mantle rocks. The predicted water concentration in average mantle can be determined from the modeled present-day water content of the mantle.

Dixon et al., [2002] proposed an average hydration of the most primitive mantle components of $750 \pm 250$-ppm. Unfortunately the large uncertainty in this value prevents us from putting tighter constraints on the likely model parameters. If we, however, assume that 750-ppm is the most likely value for the FOZO component we can conclude from Plate $2 \& 3$ that only intermediate model parameters are consistent with this value: low water outgassing efficiencies together with high subduction induced regassing of the mantle results in too high water concentrations; high outgassing efficiencies and low regassing rates lead to an underestimation of the water content. Dixon et al., [2002] further proposed that slab influenced mantle components are drier containing 
Table 2. Summarized modeling results from the six example runs shown in Fig. 3. To put these values into perspective we compare our findings and assumptions to previous studies: ${ }^{1}$ [Peacock, 1990]; ${ }^{2}$ [Schmidt and Poli, 1998]; ${ }^{3)}$ [Wallmann, 2001]; ${ }^{4}$ [Hilton, et al., 2002]; ${ }^{5}\left[\right.$ Bebout, 1996]; ${ }^{6}$ [Hallam, 1992]; ${ }^{7}$ [Dixon, et al., 2002]. Our estimates for water input into subduction zones is higher than the one by Peacock, (1990) who neglected water in serpentinized mantle and lower than the one by Schmidt and Poli, [1998] who assume water saturated conditions in the crust. The range of possible water subduction rates given by Bebout, [1996] is consistent with our estimate. The estimate by Hilton et al., [2002] is significantly lower than all other estimates. Our estimates for deep water recycling (mantle regassing) are comparable to the ones by Wallmann, [2001] and also our calculated values for mantle outgassing are close to the estimate by Wallmann, [2001], which is based on the total magma production rate of sub-aerial volcanism [Schmincke, 2000]. Note, that mantle outgassing refers to water loss from the mantle to the atmosphere and does not include water released from subducting slabs, i.e. slab derived water at arc volcanoes. Phanerozoic sea-level data indicates a maximum drop in sea-level of 400-600m [Hallam, 1992].

\begin{tabular}{|c|c|c|c|c|c|c|c|}
\hline $\begin{array}{l}\text { present-day } \\
\text { values }\end{array}$ & model run a & model run b & model run c & model run d & model run e & model run f & other studies \\
\hline $\mathrm{H}_{2} \mathrm{O}$ exosphere & $18.8 \times 10^{23} \mathrm{~g}$ & $18.8 \times 10^{23} \mathrm{~g}$ & $18.8 \times 10^{23} \mathrm{~g}$ & $18.8 \times 10^{23} \mathrm{~g}$ & $18.8 \times 10^{23} \mathrm{~g}$ & $18.8 \times 10^{23} \mathrm{~g}$ & \\
\hline water subducted & $\begin{array}{l}12.0 \times 10^{20} \mathrm{~g} \\
\mathrm{Ma}^{-1}\end{array}$ & $\begin{array}{l}12.0 \times 10^{20} \mathrm{~g} \\
\mathrm{Ma}^{-1}\end{array}$ & $\begin{array}{l}12.0 \times 10^{20} \mathrm{~g} \\
\mathrm{Ma}^{-1}\end{array}$ & $\begin{array}{l}12.0 \times 10^{20} \mathrm{~g} \\
\mathrm{Ma}^{-1}\end{array}$ & $\begin{array}{l}12.0 \times 10^{20} \mathrm{~g} \\
\mathrm{Ma}^{-1}\end{array}$ & $\begin{array}{l}12.0 \times 10^{20} \mathrm{~g} \\
\mathrm{Ma}^{-1}\end{array}$ & $\begin{array}{l}\text { 1) } 8.7 \times 10^{20} \mathrm{~g} \mathrm{Ma}^{-1} \\
\text { 2) }(18.5-28.0) \mathrm{x} \\
10^{20} \mathrm{~g} \mathrm{Ma}^{-1} \\
\text { 3) } 6.7 \times 10^{20} \mathrm{~g} \mathrm{Ma}^{-1} \\
\text { 4) } 1.6 \times 10^{20} \mathrm{~g} \mathrm{Ma}^{-1} \\
\text { 5) }(9.1-19.4) \times 10^{20} \\
\mathrm{~g} \mathrm{Ma}^{-1}\end{array}$ \\
\hline $\begin{array}{l}\text { outgassing } \\
\text { efficiency }\end{array}$ & $90 \%$ & $90 \%$ & $90 \%$ & $50 \%$ & $90 \%$ & $90 \%$ & \\
\hline $\begin{array}{l}\text { rehydration } \\
\text { prefactor }\end{array}$ & 0.5 & 1.5 & 1.0 & 1.0 & 1.0 & 1.0 & \\
\hline $\begin{array}{l}\text { mantle overturn } \\
\text { rate }\end{array}$ & $9.8 \mathrm{~Gy}$ & 9.8Gy & $9.8 \mathrm{~Gy}$ & $9.8 \mathrm{~Gy}$ & $5.7 \mathrm{~Gy}$ & $14.7 \mathrm{~Gy}$ & $\begin{array}{l}\text { 8) } 9.8 \mathrm{~Gy} \\
\text { 9) } 5.7 \mathrm{~Gy}\end{array}$ \\
\hline $\begin{array}{l}\text { deep recycling/ } \\
\text { mantle regassing }\end{array}$ & $\begin{array}{l}2.08 \times 10^{20} \mathrm{~g} \\
\mathrm{Ma}^{-1}\end{array}$ & $\begin{array}{l}6.24 \times 10^{20} \mathrm{~g} \\
\mathrm{Ma}^{-1}\end{array}$ & $\begin{array}{l}4.16 \times 10^{20} \mathrm{~g} \\
\mathrm{Ma}^{-1}\end{array}$ & $\begin{array}{l}4.16 \times 10^{20} \mathrm{~g} \\
\mathrm{Ma}^{-1}\end{array}$ & $\begin{array}{l}4.16 \times 10^{20} \mathrm{~g} \\
\mathrm{Ma}^{-1}\end{array}$ & $\begin{array}{l}4.16 \times 10^{20} \mathrm{~g} \\
\mathrm{Ma}^{-1}\end{array}$ & $\begin{array}{l}\text { 3) }(1.62-4.14) \mathrm{x} \\
10^{20} \mathrm{~g} \mathrm{Ma}^{-1}\end{array}$ \\
\hline $\begin{array}{l}\text { mantle } \\
\text { outgassing }\end{array}$ & $\begin{array}{l}4.41 \times 10^{19} \mathrm{~g} \\
\mathrm{Ma}^{-1}\end{array}$ & $\begin{array}{l}9.64 \times 10^{19} \mathrm{~g} \\
\mathrm{Ma}^{-1}\end{array}$ & $\begin{array}{l}7.02 \times 10^{19} \mathrm{~g} \\
\mathrm{Ma}^{-1}\end{array}$ & $\begin{array}{l}7.38 \times 10^{19} \mathrm{~g} \\
\mathrm{Ma}^{-1}\end{array}$ & $\begin{array}{l}8.25 \times 10^{19} \mathrm{~g} \\
\mathrm{Ma}^{-1}\end{array}$ & $\begin{array}{l}7.18 \times 19^{19} \mathrm{~g} \\
\mathrm{Ma}^{-1}\end{array}$ & $\begin{array}{l}\text { 3) }(3.6-5.4) \times 10^{19} \\
\mathrm{~g} \mathrm{Ma}^{-1}\end{array}$ \\
\hline $\mathrm{H}_{2} \mathrm{O}$ mantle & $4.88 \times 10^{23} \mathrm{~g}$ & $10.7 \times 10^{23} \mathrm{~g}$ & $7.80 \times 10^{23} \mathrm{~g}$ & $14.6 \times 10^{23} \mathrm{~g}$ & $5.38 \times 10^{23} \mathrm{~g}$ & $11.9 \times 10^{23} \mathrm{~g}$ & \\
\hline $\mathrm{H}_{2} \mathrm{O}$ total & $23.6 \times 10^{23} \mathrm{~g}$ & $29.5 \times 10^{23} \mathrm{~g}$ & $26.5 \times 10^{23} \mathrm{~g}$ & $33.4 \times 10^{23} \mathrm{~g}$ & $24.2 \times 10^{23} \mathrm{~g}$ & $30.610^{23} \mathrm{~g}$ & \\
\hline $\begin{array}{l}\% \text { of exosphere } \\
\text { water in mantle }\end{array}$ & $26 \%$ & $57 \%$ & $42 \%$ & $78 \%$ & $29 \%$ & $63 \%$ & \\
\hline mantle water loss & $79 \%$ & $64 \%$ & $71 \%$ & $56 \%$ & $78 \%$ & $61 \%$ & \\
\hline mantle degassing & $90 \%$ & $90 \%$ & $90 \%$ & $72 \%$ & $96 \%$ & $79 \%$ & \\
\hline $\mathrm{H}_{2} \mathrm{O}$ in $\mathrm{FOZO}$ & 590-ppm & 738-ppm & 663-ppm & 834-ppm & 604-ppm & 766-ppm & 7) $\sim 750-\mathrm{ppm}$ \\
\hline$\varnothing \mathrm{H}_{2} \mathrm{O}$ in mantle & 122-ppm & 268-ppm & 195-ppm & 365-ppm & 134-ppm & 297-ppm & 7) $<400$-ppm \\
\hline $\begin{array}{l}\text { Phanerozoic sea- } \\
\text { level drop }\end{array}$ & $186 \mathrm{~m}$ & $605 \mathrm{~m}$ & $397 \mathrm{~m}$ & $386 \mathrm{~m}$ & $386 \mathrm{~m}$ & $389 \mathrm{~m}$ & 6) $<400-600 \mathrm{~m}$ \\
\hline
\end{tabular}

less than 400-ppm water and that the MORB source contains only about 100 -ppm. If we assume that 400-ppm is an upper bound for the average mantle value we can again rule out combined low outgassing and high recycling efficiencies and thereby a very 'wet' mantle.

As an additional constraint we use observed sea-level changes. The Hallam, [1992] sea-level curve suggests a maximum sea-level drop of 400-600m during the Phanerozoic while Artyushkov and Chekhovich, [2001] argue against significant sea-level changes. Given the 'dynamics' of water outgassing and water recycling it appears to us almost inevitable that the global ocean volume has changed through time and with it sea-level. Nevertheless, a conservative upper bound for maximum sea-level drop over the past $600 \mathrm{Ma}$ is $400 \mathrm{~m}$. In order to convert our findings on variations in ocean volume into sea-level changes we assume that the continent-ocean distribution and the average ocean depth have not changed through time. These are, of course, 'strong' (and hard to constrain) assumptions but since we use predicted sea-level changes only as a 'control' parameter such a rough estimate is sufficient. Changes in sea-level, $h$, can therefore be expressed as $h=V_{\text {past }} / V_{\text {now }} * d_{\text {now }}-d_{\text {now }}$, where $V$ is the past and present ocean volume, respectively, and $d_{\text {now }}=3800 \mathrm{~m}$ is the present average depth of the oceans. The 
effect of increasing the amount of water in the present-day exosphere

$$
1.67 \times 10^{21} \mathrm{~kg} \quad 1.88 \times 10^{21} \mathrm{~kg} \quad 2.09 \times 10^{21} \mathrm{~kg}
$$

initial water [exospheres]
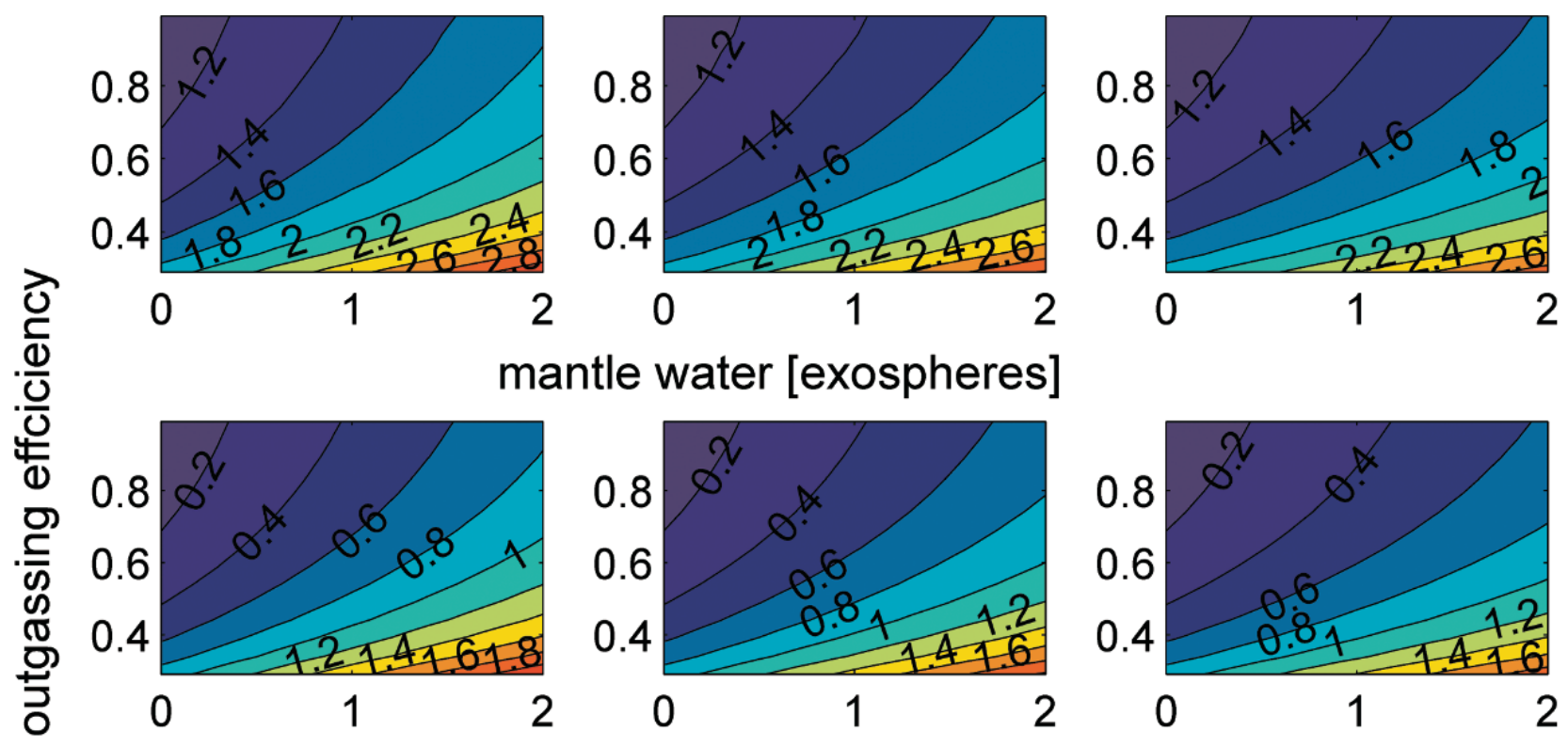

mantle water [exospheres]
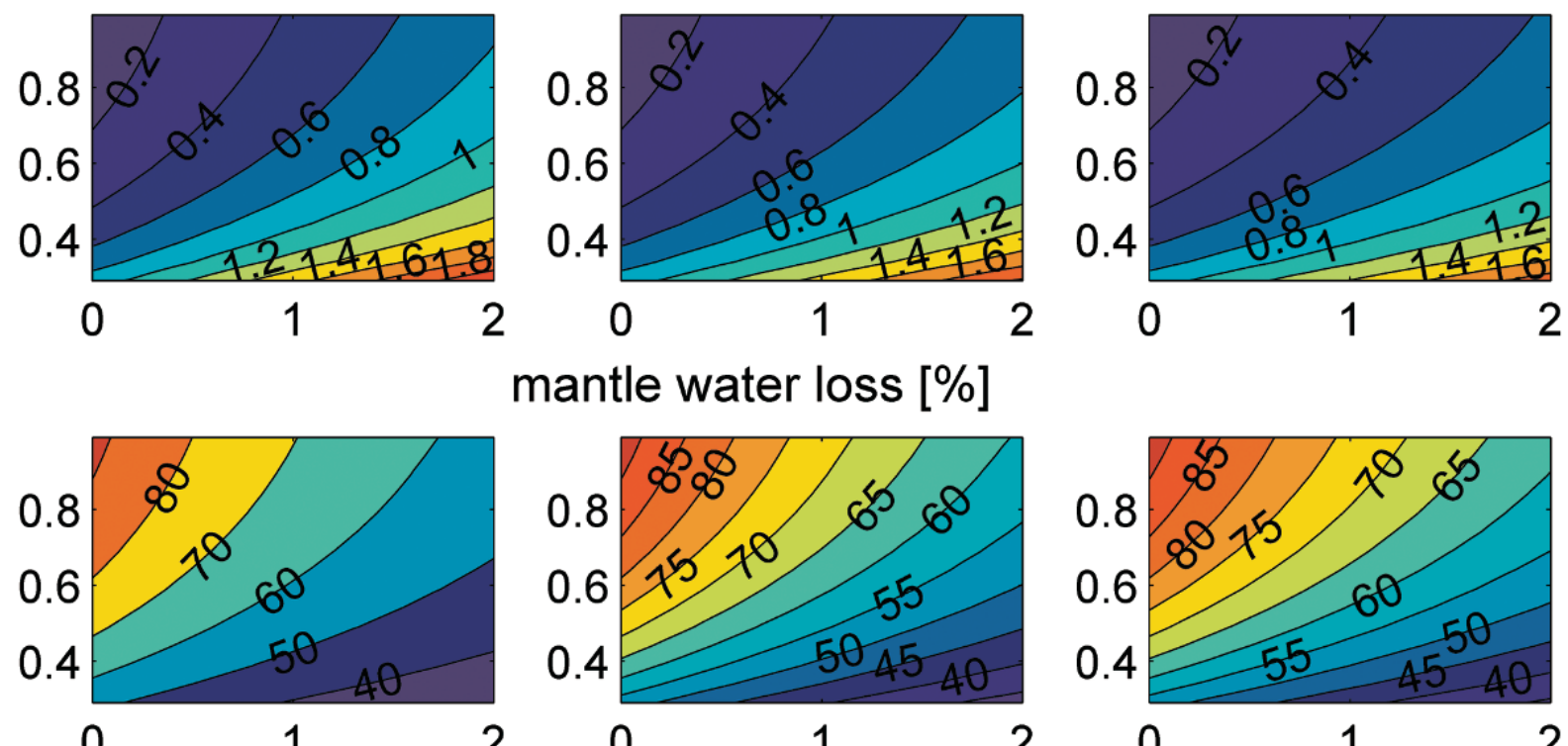

\section{present-day regassing rate $\left[4.16 \times 10^{20} \mathrm{~g} \mathrm{Ma}^{-1}\right]$}

Plate 2. Phase diagram of all model runs. The y-axis of all plots describe the assumed outgassing efficiency which varies between $30 \%$ and $99 \%$. The $\mathrm{x}$-axis in all plots describe mantel regassing rates through plate subduction as multiples of the present-day rate of $4.16 \times 10^{20} \mathrm{~g} \mathrm{H}_{2} \mathrm{O} \mathrm{Ma}^{-1}$. Multiplication of the numbers for water content of the mantle with the assumed water content of the exosphere (see top of each column) gives mantle water contents in $\mathrm{kg}$. 
effect of increasing the amount of water in the present-day exosphere

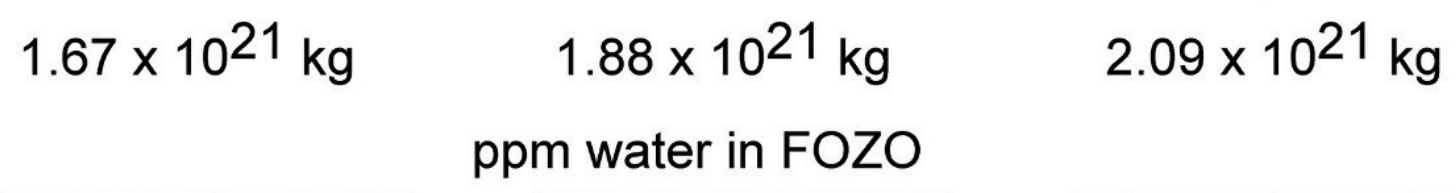
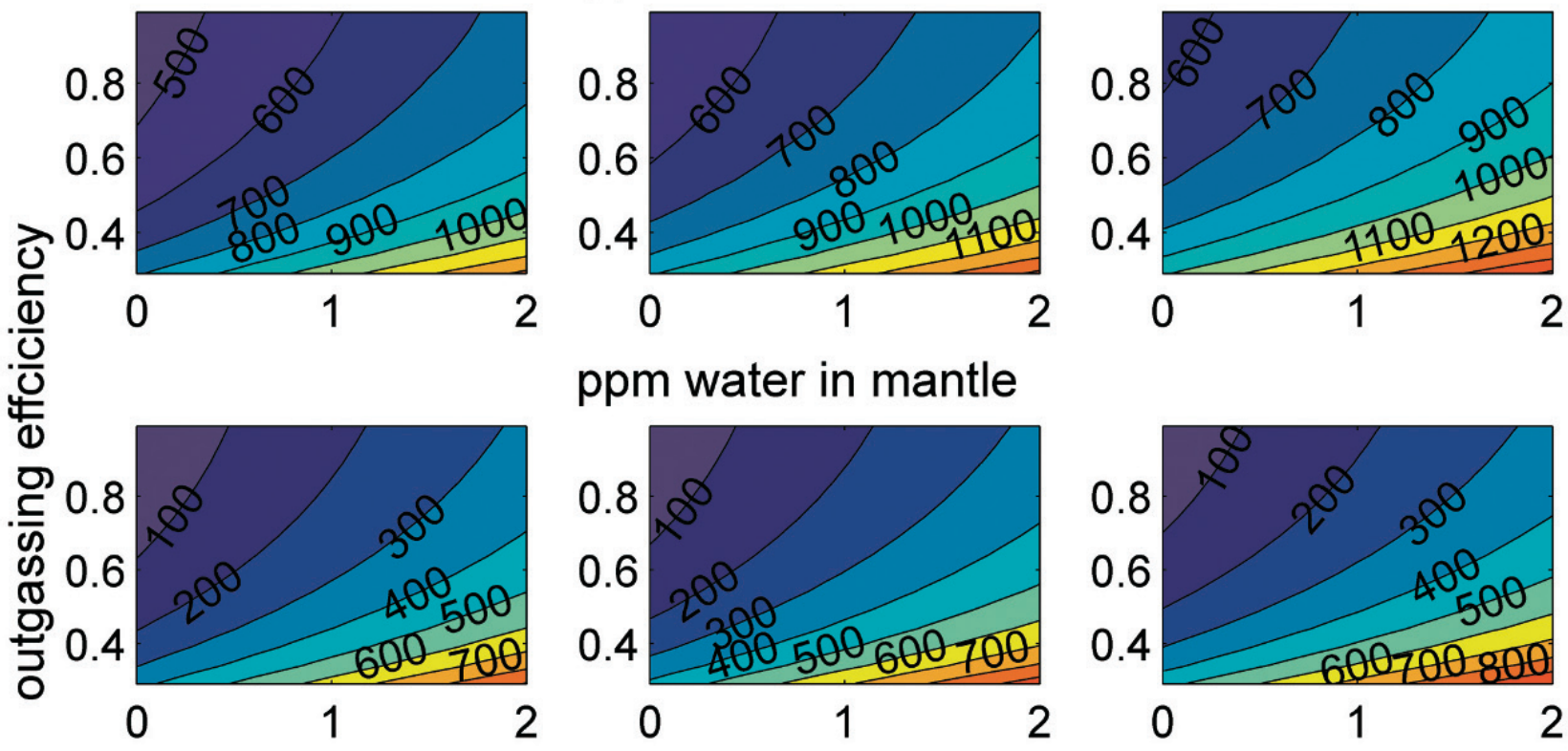

ppm water in mantle

Phanerozoic sealevel drop [m]
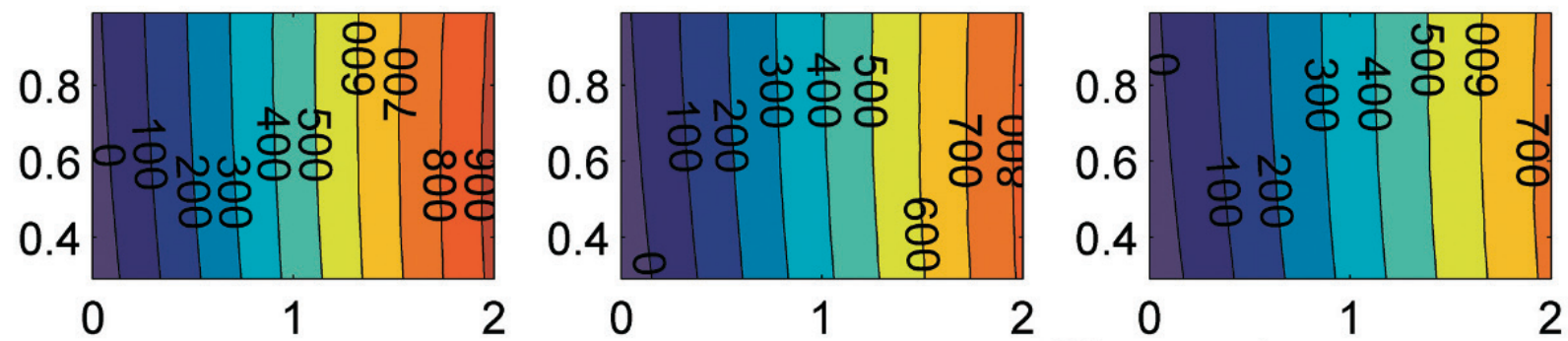
present-day regassing rate $\left[4.16 \times 10^{20} \mathrm{~g} \mathrm{Ma}^{-1}\right]$

Plate 3. Phase diagram of all model runs. The axes are the same as in Plate 2. See text for details. 
last panel plots in Plate 3 show the predicted drop in sea-level over the past $600 \mathrm{Ma}$ for all the model runs. These plots show that it is mainly the intensity of subduction rehydration that controls this number: strong water recycling leads to larger sea-level drops through time. Using the upper bound of $400 \mathrm{~m}$ for Phanerozoic sea-level changes we can rule out presentday water recycling rates greater than about $1 \times 4.16 \times 10^{20} \mathrm{~g}$ $\mathrm{Ma}^{-1}$ - a result that is consistent with box-modeling of the global water cycle [Wallmann, 2001].

We can now infer mantle evolution scenarios that are consistent with the geochemical data and the sea-level constraints. Two end-member evolution models appear plausible. The fist scenario is what we call the 'water-world' model. Mantle regassing rates through plate subduction have increased over the past $2 \mathrm{Ga}$ to the present-day value of about $4.16 \times 10^{20} \mathrm{~g} \mathrm{H}_{2} \mathrm{O} \mathrm{Ma}{ }^{-1}$ leading to significant sea-level changes throughout Earth history. All outgassing efficiencies between the upper bound of $99 \%$ and the lower bound of $50 \%$ are consistent with the geochemical constraints (Plate $2 \& 3)$. In this scenario plate subduction plays an important role in connecting the Earth's surface and deep water cycles. A major drop in ocean volume over the past $\sim 2 \mathrm{Ga}$ resulted in significant changes in land-sea distribution, and possibly in the emergence of large parts of the continents.

In the second end-member scenario sea-level has not changed significantly during the last $2 \mathrm{Ga}$, which requires that subducting plates dehydrate efficiently so that only little or no water is recycled into the deeper mantle. This scenario requires much lower $(\sim 50 \%)$ outgassing efficiencies for the modeling results to be consistent with the geochemical constraints.

At this point we favor the 'water-world' scenario but additional data will be required to discriminate between these two end-member models. We can, however, conclude that none of the scenarios explored results in a very wet mantle, i.e. one that has several oceans of water dissolved in it.

\section{DISCUSSION AND CONCLUSIONS}

These findings are somewhat contrary to some recent studies that proposed a transition zone that is much wetter than the average mantle (e.g. [Bercovici and Karato, 2003; Huang, et al., 2005; Ohtani, 2005; Smyth, 1987]). In fact, Bercovici and Karato, [2003] formulated the hypothesis of the 'transition zone water filter' to explain the observed chemical differences between OIB and MORB. In this study we neglect potential preferential water storage in a 'mantle acquifer' such as the transition zone. This model assumption is based on our results on efficient plate dehydration during subduction and the chemical evidence presented by Dixon et al., [2002]. Our recent work on slab dehydration presented here and in [Rüpke, et al., 2004] implies that it is unlikely that slabs remain sufficiently cold and hydrated during subduction to eventually exceed the water storage capacity of deeper mantle rocks. Such a super-saturation of subducting slabs is, however, critical for forming a fluid phase deep inside the mantle that could possibly lead to preferential water storage inside the transition zone. Furthermore, preferential water storage or water stripping from hydrated mantle material flowing through the transition zone should fractionate water from its magmatic sister element Ce. However, Dixon et al.,'s [2002] results do not show such a fractionation. We therefore feel that this is a valid approximation and that the here presented model incorporates the major geologic processes affecting Earth's deep water cycle. If, however, a highly hydrated transition zone does exist, then our prediction of the mantle's hydration state will need to be revised.

In conclusion, it appears likely that Earth's mantle contains less water than the exosphere (oceans plus crust) and we suggest that the equivalent of one exosphere is an upper bound for the total water content of the mantle (see Plate $2 \& 3$ ). Earth's mantle appears therefore to be rather 'dry' or 'damp' than 'wet' as a result of water outgassing at mid-ocean ridges and hotspots, which mitigates mantle rehydration by plate subduction. This finding is supported by the fact that our model predicts realistic water concentrations for the different mantle components - concentrations consistent with the independent estimates by Dixon et al. [2002].

One interesting aspect of our findings is that practically all models predict water concentrations in 'average' mantle that are higher than the 'normal' water concentration of 100 -ppm in the MORB source. In fact, the strikingly homogeneous geochemistry of MORB relative to OIB is one of the most remarkable observations in geochemistry. Phipps Morgan and Morgan, [1999] proposed the two-stage melting model to explain this observation, in which the MORB source represents the 'left-overs' of plume melting beneath hotspots. Applying this model to the water concentrations determined here for the average mantle leads to the following concept: if mantle melting preferentially occurs first in its most volatile-rich or incompatible element-rich components (plausible since both volatiles and incompatible elements tend to reduce the solidus), then it would be completely consistent that hotspots with a FOZO-component in their source will make wetter basalts than hotspots whose mantle sources contain a larger fraction of EM and HIMU components, and also consistent that progressive upwelling and pressure-release melting beneath a mid-ocean ridge should eventually be able to melt the average mantle to the point where $\sim 100$-ppm depleted, slab influenced mantle components are the only remaining water source to contribute to the more depleted MORB. Thus our results 


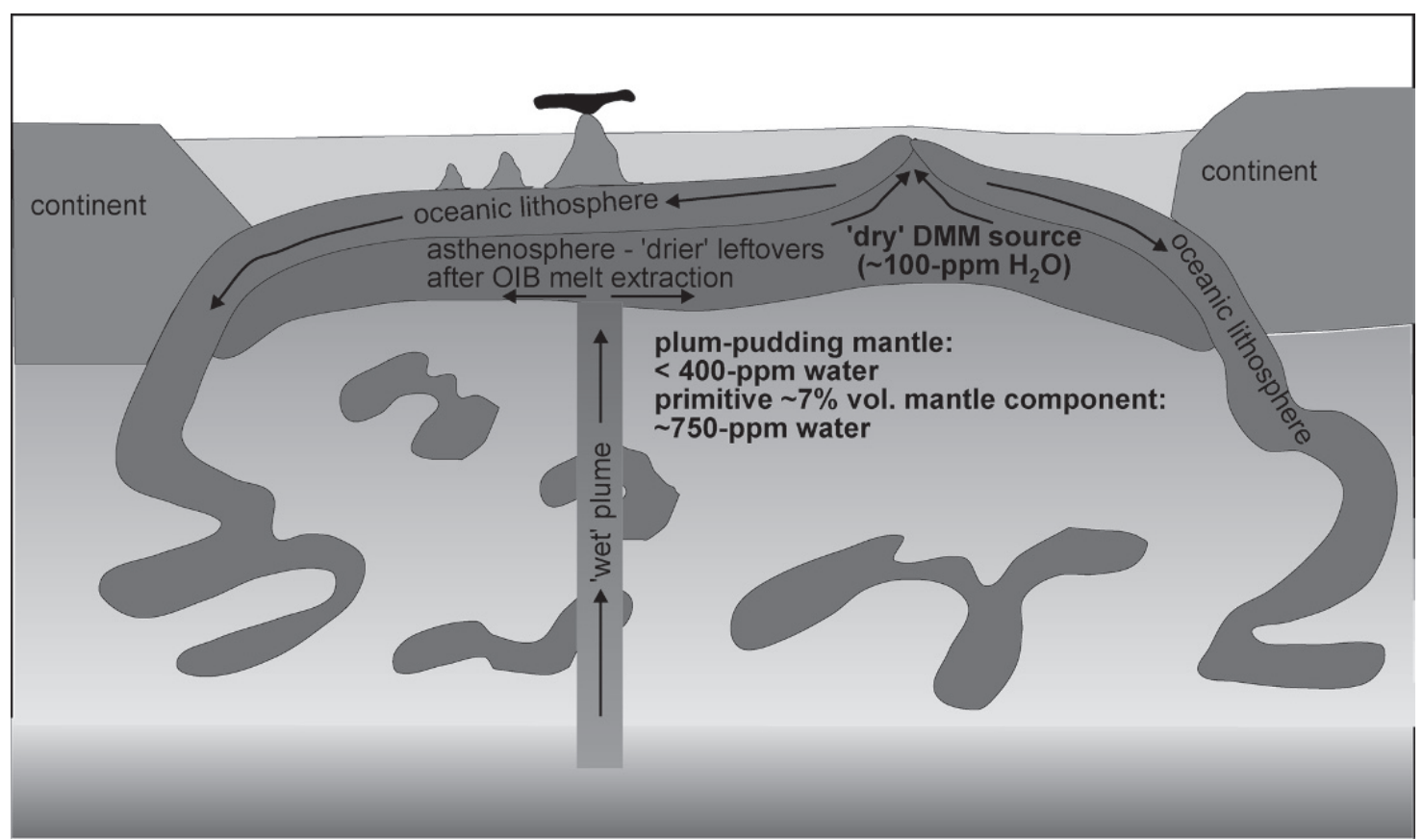

Figure 4. The plume-pudding mantle model. 'Left-overs' from hotspot melting feed the asthenosphere that melts beneath mid-ocean ridges to make MORB. This two-stage melting model may explain the low water content of the MORB source and its remarkable homogeneous chemistry with respect to OIB.

(summarized in Fig. 4) are consistent with a plum-pudding whole mantle convection evolution scenario in which plate subduction plays an important role in partially filtering the water content of the recycled sediments and ocean basalts that form the sources of the more enriched mantle plums.

Acknowledgments. Many thanks to Terry Plank, Suzan van der Lee, Steve Jacobsen, and an anonymous reviewer for very constructive and helpful comments on the manuscript. Fruitful discussions with Matthias Hort greatly helped to develop the ideas for this study.

\section{REFERENCES}

Artyushkov, E. V., and P. A. Chekhovich (2001), The East Siberian basin in the Silurian: evidence for no large-scale sea-level changes, Earth Planet. Sci. Lett., 193, 183-196.

Asimow, P., J. E. Dixon, and C. Langmuir (2004), A hydrous melting and fractionation model for mid-ocean ridge basalts: Application to the Mid-Atlantic Ridge near the Azores, Geochemistry Geophysics Geosystems, 5, doi: 10.1029/2003GC000568.

Bebout, G. E. (1996), Volatile Transfer and Recycling at Convergent Margins: Mass-Balance and Insights from High-P/T Metamorphic Rocks, in Subduction Top to Bottom, edited by G. E. Bebout, et al., pp. 179-193, American Geophysical Union, Washington DC.

Bercovici, D., and S. Karato (2003), Whole-mantle convection and the transition-zone water filter, Nature, 425, 39-44.
Chase, C. G. (1979), Subduction, the geoid, and lower mantle convection, Nature, 282, 464-468.

Dixon, J. E., and D. A. Clague (2001), Volatiles in basaltic glasses from Loihi Seamount, Hawaii: Evidence for a relatively dry plume component, J. Petrol., 42, 627-654.

Dixon, J. E., L. Leist, C. Langmuir, and J.-G. Schilling (2002), Recycled dehydrated lithosphere observed in plume-influenced mid-ocean-ridge basalt, Nature, 420.

Drake, M. J., and K. Righter (2002), Determining the composition of the Earth, Nature, 416, 39-44.

Grevemeyer, I., E. R. Flueh, C. Ranero, D. Klaeschen, and J. Bialas (2006), Passive and active seismological study of bending-related faulting and mantle serpentinization at the Middle America trench, Earth Planet. Sci. Lett., submitted.

Grevemeyer, I., N. Kaul, J. L. Diaz-Naveas, H. W. Villinger, C. R. Ranero, and C. Reichert (2005), Heat flow and bendingrelated faulting at subduction trenches: Case studies offshore of Nicaragua and Central Chile, Earth Planet. Sci. Lett., 236, 238-248.

Hallam, A. (1992), Phanerozoic Sea-Level Changes, Columbia University Press.

Hart, S. R., L. A. Hauri, L. A. Oschman, and J. A. Whitehead (1992), Mantle plumes and entrainment: isotopic evidence, Science, 256, 517-520.

Henderson, P. (1986), Inorganic Geochemistry, Pergamon Press.

Hilton, D. R., T. P. Fischer, and B. Marty (2002), Noble gases and volatile recycling at subduction zones, in Noble Gases In Geochemistry And Cosmochemistry, edited, pp. 319-370. 
Hirschmann, M., C. Aubaud, and A. Withers (2005), Storage capacity of $\mathrm{H} 2 \mathrm{O}$ in nominally anhydrous minerals in the upper mantle, Earth Planet. Sci. Lett., 236, 167-181.

Hofmann, A. W. (1997), Mantle geochemistry: the message from oceanic volcanism, Nature, 385, 219-229.

Hofmann, A. W., and W. M. White (1982), Mantle plumes from ancient oceanic crust, Earth Planet. Sci. Lett., 57, 421-436.

Huang, X., Y. Xu, and S. Karato (2005), Water content in the transition zone from electrical conductivity of wadsleyite and ringwoodite, Nature, 434, 746-749.

Kellogg, L. H., and G. J. Wasserburg (1990), The role of plumes in mantle helium fluxes, Earth Planet. Sci. Lett., 99, 276-289.

Marone, M., M. van der Meijde, S. van der Lee, and D. Giardini (2003), Joint inversion of local, regional and teleseismic data for crustal thickness in the Eurasia-Africa plate boundary region, Geophys. J. Int., 154, 499-514.

Michael, P. J. (1995), Regionally distinctive sources of depleted MORB: Evidence from trace elements and H2O, Earth Planet. Sci. Lett., 131, 301-320.

Mooney, W. D., G. Laske, and G. Masters (1998), CRUST 5.1: A global crustal model at 5 X 5, J. Geophys. Res., 103, 727.

Nataf, H.-C., and Y. Ricard (1996), 3SMAC: an a priori tomographic model of the upper mantle based on geophysical modeling, Phys. Earth Planet. Int., 95, 101-122.

Nichols, A. R., M. R. Carroll, and A. Höskuldsson (2002), Is the Iceland hotspot also wet? Evidence from the water contents of undegasssed submarine and subglacial pillow basalts, Earth Planet. Sci. Lett., 202, 77-87.

Ohtani, E. (2005), Water in the mantle, Elements, 1, 25-30.

Peacock, S. M. (1990), Fluid Processes in Subduction Zones, Science, 248, 329-337.

Phipps Morgan, J. (1998), Thermal and rare gas evolution of the mantle, Chem. Geol., 145, 431-445.

Phipps Morgan, J. (1999), The Isotope Topology of Individual Hotspot Basalt Arrays: Mixing Curves or Melt Extraction Trajectories? Geochemistry Geophysics Geosystems, 1.

Phipps Morgan, J., and J. Morgan (1999), Two-stage melting and the geochemical evolution of the mantle: a recipe for mantle plum-pudding, Earth Planet. Sci. Lett., 170, 215-239.

Plank, T., and H. Langmuir (1998), The chemical composition of subducting sediment and its conssequences for the crust and mantle, Chem. Geol., 145, 325-394.
Ranero, C. R., J. Phipps Morgan, K. D. McIntosh, and C. Reichert (2003), Bending, faulting, and mantle serpentinization at the Middle America trench, Nature, 425, 367-373.

Richard, G., M. Monnereau, and J. Ingrin (2002), Is the transition zone an empty water reservoir? Inference from numerical model of mantle dynamics, Earth Planet. Sci. Lett., 205, 37-51.

Rüpke, L. H., J. Phipps Morgan, M. Hort, and J. A. D. Connolly (2002), Are the regional variations in Central American arc lavas due to differing basaltic versus peridotitic slab sources of fluids? Geology, 30, 1035-1038.

Rüpke, L. H., J. Phipps Morgan, M. Hort, and J. A. D. Connolly (2004), Serpentine and the subduction zone wate cycle, Earth Planet. Sci. Lett., 223, 17-34.

Schmidt, M. W., and S. Poli (1998), Experimentally based water budgets for dehydrating slabs and consequences for arc magma generation, Earth Planet. Sci. Lett., 163, 361-379.

Schmincke, H.-U. (2000), Vulkanismus, Wissenschaftliche Buchgesellschaft.

Simons, K., J. E. Dixon, J.-G. Schilling, R. Kingsley, and R. Poreda (2002), Volatiles in basaltic glasses from the Easter-Salas y Gomez Seamount Chain and Easter Microplate: Implications for geochemical cycling of volatile elements, Geochemistry Geophysics Geosystems, 3, 10.1029/2001GC000173.

Smyth, J. R. (1987), beta-Mg2SsO4: A potential host for water in the mantle? Am. Mineral., 72, 1051-1055.

Stacey, F. D. (1992), Physics of the Earth, 3rd ed., Brookfield Press.

Staudigel, H., T. Plank, B. White, and H.-U. Schmincke (1996), Geochemical Fluxes During Seafloor Alteratrion of the Basaltic Upper Ocean Crust: DSDP Sites 417 and 418, in Subduction Top to Bottom, edited by G. E. Bebout, et al., pp. 19-38, American Geophysical Union.

Ten, A. A., Y. Y. Podladchikov, D. A. Yuen, T. B. Larsen, and A. V. Malevsky (1998), Comparison of mixing properties in convection with the particle-line method, Geophys. Res. Lett., 25, 3205-3208.

Wallmann, K. (2001), The geological water cycle and the volution of marine d18O values, Geochim. Cosmochim. Acta, 65, 2469-2485.

Williams, Q., and R. Hemley (2001), Hydrogen in the deep Earth, Ann. Rev. Earth Planet. Sci., 29, 365-418.

Zindler, A., and S. R. Hart (1986), Chemical Geodynamics, Ann. Rev. Earth Planet. Sci., 14, 493-571. 